\title{
Statistical analysis of factors affecting the service quality of Jetstar Pacific Airlines
}

- Huynh Huu Nhan ${ }^{1}$

- To Anh Dung ${ }^{2}$

${ }^{1}$ Ho Chi Minh city University of Technology, VNU-HCM,

2 University of Science, VNU-HCM

(Manuscript Received on August 01 ${ }^{\text {st }}$, 2015, Manuscript Revised August 27 ${ }^{\text {th }}$, 2015)

\section{ABSTRACT:}

The aim of this paper is to study the effects of service quality in Jetstar Pacific Airlines towards customer's satisfaction under the perspective of Servqual and Gronroos service quality model and the relationship between functional quality, technical quality,

Key words: Service quality, Servqual, Technical and functional quality model, Factor analysis.

\section{INTRODUCTION}

Service quality and customer satisfaction are very closely related. Understanding, building and maintaining quality are the main concerns of airlines industry today. To measure the service quality, we used Servqual and Gronroos model in various aspects of its business environment.

Several statistical methods and techniques may be used to analyze these modelsbased service quality dimensions. In particular, the so-called gap analysis can be employed in order to ascertain any actual or perceived gaps between customer expectations and perceptions of the service offered efficiency. Moreover, this analysis is to point out how management of service improvement can become more logical and integrated with respect to the prioritized service quality dimensions and their affections on increasing/decreasing service quality gaps. To this end, several methods have extensively been used. For instance, the model service of quality internal and external environment influences mediated by Jetstar Pacific Airlines images and service quality using the main statistical methods such as factor analysis and multiple linear regression.

may be simply evaluated by adopting: correlation analysis, reliability analysis, factor analysis and multiple linear regression.

Therefore from this paper, we believe that this conceptual paper will help the management of Jetstar Pacific Airlines to better understand their service quality which help them tho draw specific guidelines to meet customers expetations.

\section{SERVICE QUALITY}

\subsection{Servqual model}

Parasuraman et al. [1], [6] proposed that service quality is a function of the differences between expectation and performance along the quality dimensions. They developed a service quality model based on gap analysis. The five main gaps visualized in the model are: difference between customers' expectations and managements perceptions, difference between 
management's expectation and customers' perceptions, difference between service quality specifications and service actually delivered, difference between service delivery and communications about service delivery, difference between customers' expectations and perceived services. According to this model, the service quality is a function of perception and expectations and can be modeled as:

$$
S Q=\sum_{j=1}^{k}\left(P_{i j}-E_{i j}\right)
$$

Where: SQ: Overall service quality; k: number of attributes; $P_{i j}:$ Performance perception of stimulus $i$ with respect to attribute $j$; $E_{i j}$ : Service quality expectation for attribute $j$ that is the relevant norm for stimulus $i$.

This exploratory research was refined with their subsequent scale named Servqual for measuring customers' perceptions of service quality. Servqual has five main dimensions to measure service quality: reliability, responsiveness, assurance, empathy and tangibles.

\subsection{Functional and technical quality model}

Gronroos [6] developed service quality model with three dimensions: functional quality, technical quality and image.

Functional quality is how he/she gets the technical outcome. This is important to him/her and to his/her views of service he/she has received.

Technical quality is the quality of what consumer actually receives as a result of his/her interaction with the service firm and is important to him/her and to his/her evaluation of the quality of service.

Image is very important to service firms and this can be expected to built up mainly by technical and functional quality of service including the other factors (tradition, ideology, word of mouth, pricing and public relations).

\subsection{Research model proposed}

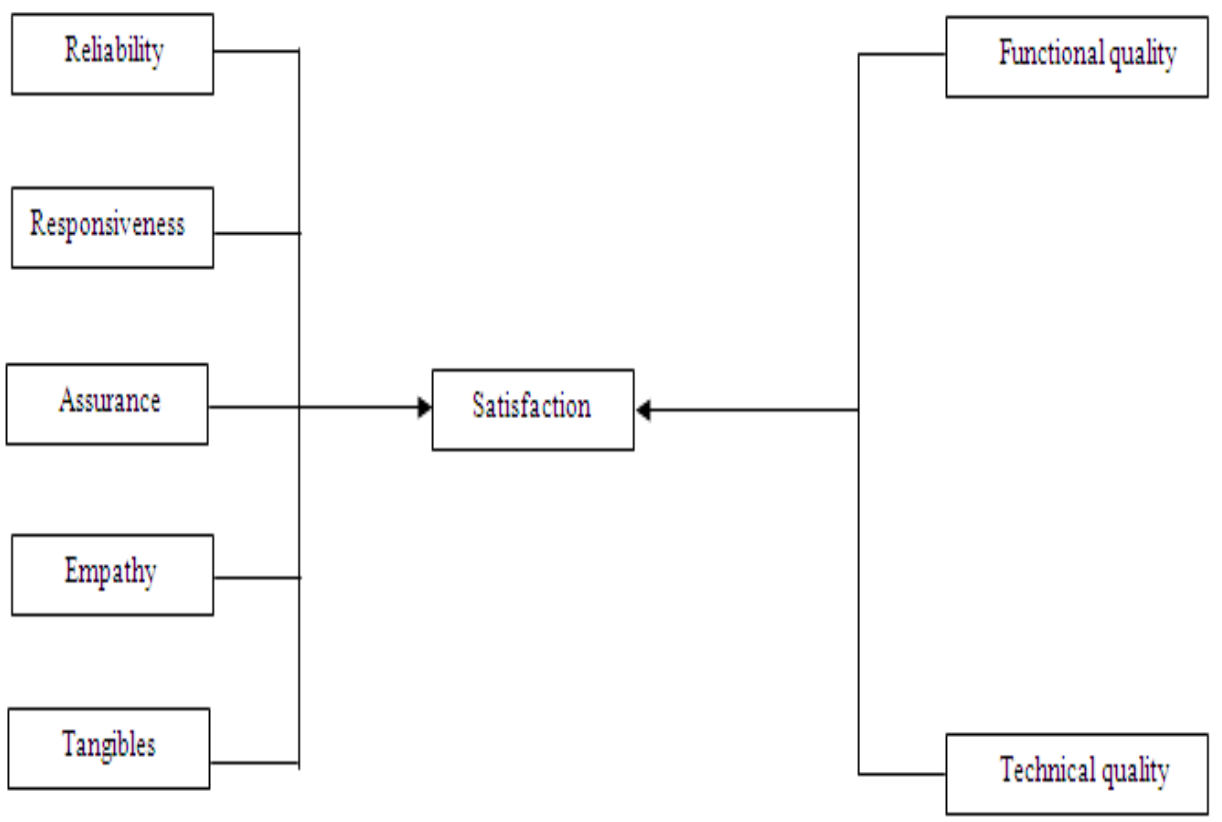

Figure 1. Research model proposed 


\section{METHODOLOGY}

\subsection{Questionnaire design}

The questions were rated using 5-point Likert scale. Perceptions were rated from $1=$ completely disagree to $5=$ strongly agree, and expectations were rated from $1=$ unimportant to $5=$ very important. The questionnaire was examined by one pilot of Jetstar Pacific Airlines and two staffs of Vietnam Airlines and their contributions were incorporated. The content validity of the questionnaire was deemed adequate. When distributed, the questionnaire was accompanied by a cover letter explaining the objective of the survey and assuring confidentiality of respondents.

\subsection{Sampling}

The sample was taken from the customers of Jetstar Pacific Airlines. A convenient sample size of 230 respondents were selected from the 300 customer surveys .The survey yielded a response rate of $76,67 \%$. The main dimensions are depicted in Table 1.

Table 1. Developed based on Gronross (1984); Parasuraman et al. (1985).

\begin{tabular}{|c|c|}
\hline Codes & Dimensions \\
\hline & Reliability \\
\hline $\mathrm{TC} 01$ & Jetstar Pacific always conducts the service as good as pledged \\
\hline $\mathrm{TC} 02$ & $\begin{array}{l}\text { When you have questions or complaints, Jetstar Pacific always provides } \\
\text { satisfying feedback and solution }\end{array}$ \\
\hline TC03 & Jetstar Pacific always informs you about the service time in advance \\
\hline TC04 & Jetstar Pacific always provides the on-time-service as promised \\
\hline \multirow[t]{2}{*}{ TC05 } & Jetstar Pacific fully carries out the service right at the first time \\
\hline & Responsiveness \\
\hline DU01 & Jetstar Pacific staffs serve you friendly and honestly \\
\hline DU02 & $\begin{array}{l}\text { Jetstar Pacific staffs always understand your request correctly with enthusiasm } \\
\text { and warm attention }\end{array}$ \\
\hline \multirow[t]{2}{*}{ DU03 } & $\begin{array}{l}\text { Jetstar Pacific staffs swiftly perform their task for completely meeting your } \\
\text { requirements }\end{array}$ \\
\hline & Assurance \\
\hline DB01 & Jetstar Pacific staffs are increasingly getting more trust from the passengers \\
\hline DB02 & You feel safe when using the service Jetstar Pacific \\
\hline DB03 & Jetstar Pacific staffs' communication is always courteous and polite \\
\hline \multirow[t]{2}{*}{ DB04 } & $\begin{array}{l}\text { Jetstar Pacific staffs have enough specialized knowledge to answer your } \\
\text { questions }\end{array}$ \\
\hline & Empathy \\
\hline DC01 & Jetstar Pacific does care about passengers \\
\hline
\end{tabular}




\begin{tabular}{|c|c|}
\hline DC02 & Jetstar Pacific staffs understand the special needs and interests of you \\
\hline DC03 & Jetstar Pacific has staffs displayed a concern for you \\
\hline \multirow[t]{2}{*}{ DC04 } & Jetstar Pacific pay attention to your great interests \\
\hline & Tangibles \\
\hline HH01 & Jetstar Pacific has a modern equipment \\
\hline HH02 & Jetstar Pacific'physical facilities look almost professional and eyecatching \\
\hline HH03 & Jetstar Pacific staffs get decent clothes \\
\hline HH04 & $\begin{array}{l}\text { Tangibles has very exciting (onboard amenities; ticket booking services at the } \\
\text { box office, by phone, via online, etc) }\end{array}$ \\
\hline \multirow[t]{2}{*}{ HH05 } & Jetstar Pacific arrange a reasonable time and a convenient tangibles \\
\hline & Functional quality \\
\hline CN01 & Jetstar Pacific staffs treat your courteously and friendly \\
\hline CN02 & $\begin{array}{l}\text { Jetstar Pacific staffs have enough specialized knowledge and capacity to make } \\
\text { you have a satisfactory explanation for their services and policies }\end{array}$ \\
\hline CN03 & Jetstar Pacific staffs keep your persional information in secret \\
\hline CN04 & Jetstar Pacific staffs are always ready to answer your questions \\
\hline CN05 & Jetstar Pacific has a meet your requirements \\
\hline \multirow[t]{2}{*}{ CN06 } & Jetstar Pacific has always done exactly the right transactions \\
\hline & Technical quality \\
\hline KT01 & Jetstar Pacific is ready to meet your needs for its services \\
\hline KT02 & $\begin{array}{l}\text { Jetstar Pacific create good for condition you to do terms of payment (pay } \\
\text { directly in cash, pay by credit or debit card, etc) }\end{array}$ \\
\hline KT03 & Service costs are competitive in Jetstar Pacific \\
\hline KT04 & Jetstar Pacific has a competitive fares \\
\hline KT05 & $\begin{array}{l}\text { Jetstar Pacific has always respond to your service requirements at the proper } \\
\text { time }\end{array}$ \\
\hline KT06 & Service Jetstar Pacific is easy and convenient for you \\
\hline KT07 & Jetstar Pacific is interested in your demand arose \\
\hline TM & Satisfaction \\
\hline TM01 & You are completely satisfied with the quality of service Jetstar Pacific \\
\hline TM02 & You will introduce the advantages of Jetstar Pacific to others \\
\hline TM03 & You will continue to use the service Jetstar Pacific in the next times \\
\hline
\end{tabular}




\section{DATA ANALYSIS}

\subsection{Discriptive statistics}

The characteristics of the respondents are presented in Table 2. In terms of gender, $70 \%$ of the respondents were males and $30 \%$ were females. $50.43 \%$ of the respondents were within

the ages of 20-35 years, $15.22 \%$ were between 36 and 50 years, $20 \%$ were between 51 and 65 years, implying that majority of them were in the economically active population.

Table 2. Respondents' characteristics $(n=230)$

\begin{tabular}{|c|c|c|c|}
\hline & & Frequency & $\%$ \\
\hline \multirow{2}{*}{ Gender } & Male & 161 & 70 \\
\hline & Female & 69 & 30 \\
\hline \multirow{5}{*}{ Age } & Under 20 & 25 & 10.87 \\
\hline & $20-35$ & 116 & 50.43 \\
\hline & $36-50$ & 35 & 15.22 \\
\hline & $51-65$ & 46 & 20 \\
\hline & Over 65 & 8 & 3.48 \\
\hline \multirow{3}{*}{$\begin{array}{c}\text { Marital } \\
\text { status }\end{array}$} & Not married yet & 50 & 27.41 \\
\hline & Married without children yet & 39 & 16.96 \\
\hline & Married and having children & 141 & 61.30 \\
\hline \multirow{6}{*}{ Occupation } & Pupil, student & 25 & 10.87 \\
\hline & Normal staff & 105 & 45.65 \\
\hline & Specialist management & 19 & 8.26 \\
\hline & Secretary, assistant & 41 & 17.83 \\
\hline & Entrepreneur, senior manager & 21 & 9.13 \\
\hline & Others & 19 & 8.26 \\
\hline
\end{tabular}

\subsection{Correlation analysis}

Correlation analysis measures the relationship between two items. The resulting value (called the "correlation coefficient") shows if changes in one item will result in changes in the other item. Figure 2 is the correlations among the variables in the analysis. 

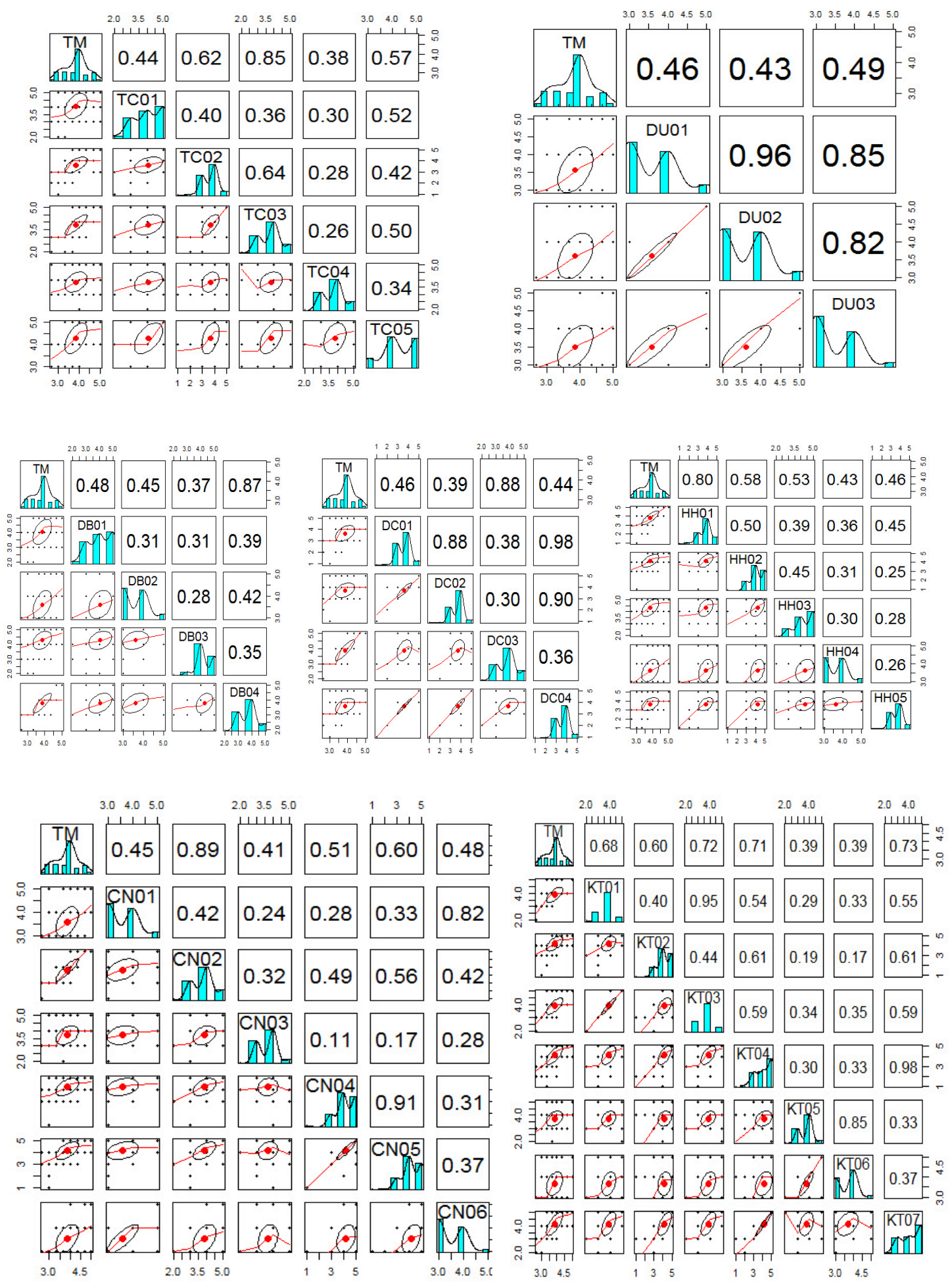

Figure 2. Correlations among the variables 


\subsection{Reliability analysis}

This measures the overall consistency of the items that are used to define a scale. As a result, we are given sample size, number of items and reliability coefficients. Cronbach's Anpha is the most popular. Table 3 show Cronbach's Anpha from 0.669 to 0.956 .

Table 3. Scale reliability

\begin{tabular}{|l|l|l|}
\hline $\begin{array}{l}\text { Multi-Item Scale } \\
\text { (Dimensions) }\end{array}$ & Cronbach's Anpha & Number of items \\
\hline Reliability & 0.768 & 5 \\
\hline Responsiveness & 0.956 & 3 \\
\hline Assurance & 0.669 & 4 \\
\hline Empathy & 0.872 & 4 \\
\hline Tangibles & 0.736 & 5 \\
\hline Functional quality & 0.804 & 6 \\
\hline Technical quality & 0.866 & 7 \\
\hline Satisfaction & 0.760 & 3 \\
\hline
\end{tabular}

\subsection{Factor analysis}

Factor analysis is a data reduction technique that uses correlations between data variables. The results of the factor analysis show a high value from 0.5 to 1 for the Kaiser-Meyer-Olkin Measure and indicate the suitability of the research data. This is confirmed by the significance of the Bartlett's test of sphericity tests. On the criteria for selecting factor loading, generally factor loading above 0.5 is considered. Other factor loadings that do not satisfy the above criteria are considered meaningless and can be removed, while the high loading factors are critical factors and therefore can be retained. Table 4 show the results of factor analysis.

Table 4. Regrouping of questonaire items

\begin{tabular}{|c|c|c|}
\hline $\begin{array}{l}\text { Emerged } \\
\text { factor }\end{array}$ & Retained Items & $\begin{array}{l}\text { Labels for component } \\
\text { dimensions }\end{array}$ \\
\hline $\mathrm{X}_{1}$ & CN01, CN06, DU01, DU02, DU03, DB02, HH04 & Perception of responsiveness \\
\hline $\mathrm{X}_{2}$ & DC01, DC02, DC04, KT05, KT06, CN03, HH05 & Perception of empathy \\
\hline $\mathrm{X}_{3}$ & TC02, TC03, HH01, CN02, DC03, DB04 & Perception of expertise \\
\hline $\mathrm{X}_{4}$ & CN04, CN05, HH02, KT02 & Perception of usefulness \\
\hline $\mathrm{X}_{5}$ & DB01, TC01, TC05, HH03 & Perception of environment \\
\hline
\end{tabular}

4.5. Multiple linear regression

Results factor analysis used to handle multiple linear regression. The results are presented in Figure 3.

Linear model:

$$
T M=0.72171+0.72167 X_{3}+0.09259 X_{5}
$$




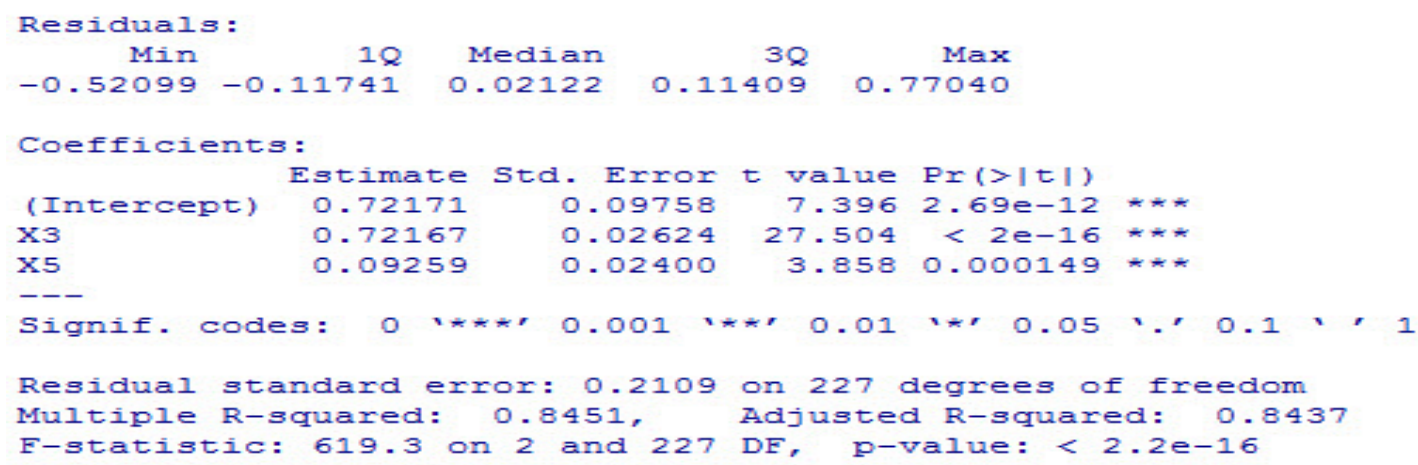

Figure 3. Multiple linear regression results

\section{CONCLUSIONS}

Research model proposed seven factors affecting the service quality of Jetstar Pacific Airlines include: reliability, responsiveness, assurance, empathy, tangibles, functional quality and technical quality. After evaluating the reliability and factor analysis, the five emerged dimensions with twenty-eight items, being "Perception of responsiveness", "Perception of empathy", "Perception of expertise", "Perception of usefulness", and "Perception of environment" could be used as critical factors in evaluating service quality in Jetstar Pacific Airlines. Results of multiple linear regression multivariate linear regression analysis identified the service quality of Jetstar Pacific Airlines affected by two emergerd factors are "Perception of expertise" and "Perception of environment". 


\section{Phân tích thống kê các nhân tố ảnh hưởng đến chất lượng dịch vụ hãng hàng không Jetstar Pacific}

- Huỳnh Hữu Nhân 1

- Tô Anh Dũng ${ }^{2}$

${ }^{1}$ Trường Đại học Bách khoa, ĐHQG-HCM

${ }^{2}$ Trường Đại học Khoa học Tự nhiên, ĐHQG-HCM

TÓM TÁ́T:

Mục tiêu của báo cáo này là nghiên cứu các nhân tố tác động tới sự hài lòng của khách hàng về chất lượng dịch vụ của hãng hàng không Jetstar Pacific theo quan điểm Servqual và Gronroos, cũng như mối quan hệ giữa chất lượng chức năng, chất lượng kỹ thuật, ảnh hưởng môi trường bên trong và môi trường bên ngoài thông qua hình ảnh và dịch vụ của hãng sử dụng các phương pháp thống kê chính như phân tích nhân tố và hồi quy tuyến tính đa biến.

Từ khóa: Chất lượng dịch vụ, Servqual, Mô hình chất lượng chức năng và kỹ thuật, Phân tích nhân tố

\section{REFERENCES}

[1]. Ciavolino E., \& Calcagni A., Generalized cross entropy method for analysis the SERVQUAL model, Journal of Applied Statistics (2014).

[2]. Hoàng Trọng \& Chu Nguyễn Mộng Ngọc, Phân tích dũ liệu nghiên cúu với SPSS, Tập 1 và Tập 2, NXB. Hồng Đức (2008).

[3]. Nguyễn Văn Tuấn, Phân tích dũ liệu với $R$, NXB. Tổng Hợp TPHCM (2014).

[4]. Pakdil F. \& Adyin O., Expectations and perceptions in airline service: An analysis using weighted SERQUAL, Journal of Air Transport Management (2007).

[5]. Rencher A.C., Methods of multivariate analysis, A Wiley - Interscience Publication (2002).

[6]. Seth N., Deshmukh S., \& Vrat P., Service quality models: A review, International Journal of Quality and Reliability Management (2005).

[7]. Trần Thị Kim Thu, Giáo trình lý thuyết thống kê, NXB. Đại Học Kinh Tế Quốc Dân (2013). 